Prace Filologiczne. Literaturoznawstwo 10(13) 2020

ISSN 2084-6045

e-ISSN 2658-2503

Creative Commons: Uznanie autorstwa 3.0 PL (CC BY)

DOI: $10.32798 /$ pflit.577

\title{
MIĘDZY AGONEM A ANTAGONIZMEM. CHORWACKIE KONCEPCJE IDEI POLITYKI*
}

\section{Between Agon and Antagonism. Croatian Concepts of the Idea of Politics}

\author{
EWA WRÓBLEWSKA-TROCHIMIUK \\ Instytut Slawistyki Polskiej Akademii Nauk, Polska \\ E-mail: ewa.wroblewska@ispan.waw.pl
}

ORCID: 0000-0002-1594-3306

\begin{abstract}
The aim of the article is to present the idea of politics that has been developing in the modern approach since the Enlightenment in the context of the concepts of agonism and antagonism in the view of the Belgian philosopher Chantal Mouffe. The research material will be constituted by Croatian political writings (mainly from the nineteenth and twentieth centuries), which is the field where the authors have developed local versions of the dominant conceptions of politics, indicating its purpose, scope, and social role in relation to local conditions. Following changes taking place within the concept of politics allows to demonstrate how the idea of political agon and agonistics, understood as an area of fundamental social and cultural conflict, has developed within the Croatian cultural context.
\end{abstract}

Keywords: agonistics, politics, political agon, Chantal Mouffe, Croatia, political writing

\section{Streszczenie}

Celem artykułu jest zaprezentowanie idei polityki rozwijającej się w nowoczesnym ujęciu od czasów oświecenia w kontekście pojęć agonizmu i antagonizmu w ujęciu belgijskiej filozofki Chantal Mouffe. Za materiał badawczy posłuży chorwackie piśmiennictwo polityczne (głównie z XIX i XX wieku), będące polem, na którym autorzy rozwijali rodzime wersje dominujących koncepcji polityki, wskazując jej cel, zakres i rolę społeczną w odniesieniu do lokalnych uwarunkowań. Prześledzenie zmian zachodzących w obrębie idei polityki pozwoli zademonstrować, w jaki sposób na chorwackim gruncie rozwijała się idea agonistyki i agonu politycznego.

Słowa kluczowe: agonistyka, polityka, agon polityczny, Chantal Mouffe, Chorwacja, piśmiennictwo polityczne

* Artykuł powstał w ramach projektu „Wizualne artykulacje oporu politycznego w Chorwacji i Serbii po roku 2000", nr 2018/31/HS2/03127, finansowanego przez Narodowe Centrum Nauki. Publikacja artykułu dofinansowana przez Uniwersytet Warszawski. 
Idea polityki nie rozwijała się na gruncie kultury chorwackiej w historycznej próżni. Koncepcje rodzące się w kręgach chorwackich intelektualistów i ideologów stanowiły wyraźny oddźwięk i rozwinięcie prądów myślowych w innych, najczęściej zachodnioeuropejskich, ośrodkach politycznych. Za specyfikę tego regionu można jednak uznać mariaż sfery politycznej i literackiej. Chorwaccy działacze polityczni rekrutowali się najczęściej ze środowisk twórczych albo zasilali szeregi chorwackich pisarzy, sprawnie łącząc formację ideologiczną z możliwością komunikacji, którą dawało uczestnictwo w życiu literackim. Sposobów rozumienia idei polityki szukać należy nie tylko w manifestach mężów stanu czy programach partii, ale również w tekstach literackich i publicystyce, które stały się równoprawnym obszarem formułowania poglądów.

W niniejszym artykule zamierzam prześledzić zmiany zachodzące w sposobie rozumienia idei polityki na chorwackim gruncie kulturowym i skonfrontować je z pojęciami agonizmu i antagonizmu w rozumieniu filozofki Chantal Mouffe ${ }^{1}$. Za materiał badawczy posłuży chorwackie piśmiennictwo polityczne (głównie z XIX i XX wieku), w którym autorzy rozwijali rodzime wersje dominujących koncepcji polityki, wskazując jej cel, zakres i rolę społeczną w odniesieniu do lokalnych uwarunkowań. Należy zaznaczyć, że Chantal Mouffe wypracowała teorię agonistycznego modelu polityki w kontekście liberalnej i pluralistycznej demokracji, a zatem systemu rządów i sprawowania władzy, który na badanym obszarze w pełni rozwiną się dopiero pod koniec wieku XX. Jednakowoż zjawiska agonizmu i antagonizmu zamierzam traktować jako swoiste modele pełniące funkcję heurystycznych narzędzi, które pozwolą odkryć dynamikę ewolucji idei polityki w kulturze chorwackiej.

Podstawą koncepcji Mouffe jest założenie, że czynnikiem fundującym nowoczesne społeczeństwa są nierozwiązywalne i nieprzezwyciężalne konflikty wynikające $\mathrm{z}$ potrzeby ustanawiania przez różne grupy społeczne hegemonii, czyli porządków społecznych adekwatnych do potrzeb i oczekiwań danej grupy ${ }^{2}$. Wobec każdej hegemonii i ustanawiających ją praktyk społeczeństwa wytwarzają alternatywy polegające na interwencji $\mathrm{w}$ dominujący porządek władzy. Interwencje te podyktowane są przekonaniem, że żaden porządek nie jest stanem naturalnym i możliwe jest ustanowienie innego. Agonizm - czy agoniczny model demokracji, jak nazywa go Mouffe - jest więc praktyką kwestionowania istniejącej hegemonii podszytą dążeniem do wykreowania porządku świata dostosowanego do własnych interesów ${ }^{3}$. Prymarną zasadą agonizmu jest uznanie prawomocności żądań i dążeń politycznych oponentów, co znacząco różni

\footnotetext{
${ }^{1}$ Ch. Mouffe, Paradoks demokracji, tłum. W. Jach et al., Wrocław 2005.

${ }^{2}$ Ch. Mouffe, Agonistyka. Polityczne myślenie o świecie, tłum. B. Szelewa, Warszawa 2015, s. $17-19$.

${ }^{3}$ Ibidem, s. 21-24.
} 
ten model polityki od modelu antagonistycznego, w którym nie uznaje się prawomocności żądań oponenta. Agonistyka jest więc polityczną walką o to, by „nasza” interpretacja zyskała hegemonię, ale zakłada szacunek i uznanie prawa innych do takiej samej walki. Grupy pozostające po różnych stronach politycznej barykady są zgodne co do fundamentalnych zasad demokracji, ale - jak pisze Mouffe - ,zawsze będzie panowała niezgoda co do znaczenia tych wartości i sposobu ich wprowadzania"4. W modelu agonistycznym mamy więc do czynienia $z$ oponentem, natomiast $w$ modelu antagonistycznym na przeciwległym biegunie znajduje się wróg, którego należy - przynajmniej symbolicznie - unicestwić.

\section{Ku definicjom i ich źródłom}

Różne sposoby rozumienia polityki ujawniane są w pierwszej kolejności przez najpopularniejsze źródła leksykograficzne. Opublikowany w 1974 roku, a zatem jeszcze w czasie istnienia Jugosławii, Leksykon Jugosłowiańskiego Zakładu Leksykograficznego rozróżnia trzy możliwe sposoby rozumienia polityki: jako umiejętność zarządzania wspólnotami ludzkimi, jako całokształt zasad i metod stosowanych w organizacji i rozwoju państwa w odniesieniu do określonych obszarów (np. ekonomicznego), wreszcie jako zbiór środków i działań ukierunkowanych na obronę interesów określonych klas, tj. na zdobycie lub zachowanie władzy ${ }^{5}$. Z kolei wydany dziesięć lat później, więc już po rozpadzie Jugosławii, Filozofijski rječnik zawiera dość rozbudowany opis działań na rzecz państwa. Za takowe uważana jest każda czynność ukierunkowana na podtrzymywanie i postęp państwa jako wspólnoty obywateli, obronę konstytucyjnego i prawnego porządku, a także kształtowanie władzy, administracji i instytucji politycznych ${ }^{6}$. W najmłodszym $z$ dostępnych słowników filozoficznych, wydanym w $2000 \mathrm{roku}^{7}$, pojęcie polityki zostało znacząco zawężone. Zdefiniowane zostało tam w pierwszej kolejności jako uczestnictwo w życiu społecznym, następnie zaś jako działanie na rzecz państwa. Jak widać na powyższych przykładach paradoksalnie tylko definicja z 1974 roku wprowadza (choć dopiero na ostatnim miejscu) kategorię konfliktu i sporu. Nowsze definicje zupełnie tę kwestię pomijają, nie traktując polityki jako praktyki hegemoniczne wytwarzające określony porządek i równolegle do niego istniejące konstrukcje alternatywnych hegemonii. Traktują one politykę jako rodzaj odgórnego

${ }^{4}$ Ibidem, s. $22-23$.

${ }^{5}$ Politika [hasło], w: Leksikon Jugoslavenskog Leksikografskog Zavoda, Zagreb 1974.

${ }^{6}$ Filozofijski rječnik, red. V. Filipović, Zagreb 1984, s. 253.

${ }^{7}$ A. Mišić, Riječnik filozofijskih pojmova, Zagreb 2000, s. 207. Jako podstawowych filozofów polityki wymienia się Platona, Arystotelesa, św. Augustyna, św. Tomasza, a także Machiavellego, Thomasa Hobbesa, Johna Locke'a i Georga Hegla. 
zarządzania wspólnotą, pomijając jednocześnie działania oddolne społeczeństw. Źródła takiego rozumienia polityki leżą dużo głębiej, a mianowicie w szesnastowiecznym piśmiennictwie.

Chorwaccy badacze wskazują, że korzenie chorwackiej myśli politycznej sięgają początków wieku XVI, a dokładnie pracy szybenickiego humanisty Ivana Polikarpa Severitana (1472?-1526) pt. Monoregia (1522) czy dzieła pt. La città felice (1553) autorstwa polihistora, profesora na uniwersytetach w Rzymie i Ferrarze, nauczyciela Giordana Bruna, Frane Petricia $(1529-1597)^{8}$. Przeniknięta jednocześnie duchem arystotelizmu i filozofią chrześcijańską Monoregia stanowi poradnik dobrego zarządzania miastem (i państwem), mający służyć potencjalnemu władcy, który postrzegany jest jako moderator politycznej rzeczywistości. Z kolei dzieło Petricia zdradza neoplatońską formację autora, zainfekowaną dodatkowo utopizmem politycznym Tomasza Morusa. Wykazuje ono cechy eutopii, projekcji „dobrego i szczęśliwego miejsca”, do czego pisarz nawiązuje w tytule. Polihistor Petrić jednoznacznie zachęca swoich czytelników, by działając w obszarze polityki, poszukiwali historycznych praw i wzorów. Podkreśla w ten sposób pragmatyczny wymiar polityki, konieczność tworzenia i śledzenia jej zasad oraz reguł. W obu pracach polityka jawi się jednak w sposób typowy dla renesansowych odczytań filozofii antycznej, tj. nie tyle jako cel i wartość sama w sobie, ale jako narzędzie, przy pomocy którego możliwe jest osiągnięcie szczęścia i równowagi. Echa tych koncepcji można więc dostrzec we współczesnych definicjach, przy czym w miejsce kategorii szczęścia podstawione zostają tu pojęcia „postęp” czy „rozwój”. Nieco odmienne rozumienie wyczytać można z kolei z utworów dubrownickiego polihistora i polityka Nikoli Vitova Gučeticia, autora dzieła pt. Dello Stato delle Republiche (1591), stanowiącego komentarz do Polityki Arystotelesa'. Pozostając pod wpływem arystotelizmu, ale także koncepcji chrześcijańskiej i prac Awerroesa, św. Tomasza z Akwinu, Jeana Bodina oraz Francesco Patrizio, Gučetić definiuje politykę jako praktyczną umiejętność, która z jednej strony dostosowuje się do okoliczności, z drugiej zaś pozwala przystosowywać okoliczności do własnych celów. Mimo że Gučetić wskazuje na boską proweniencję władzy i praw rządzących światem, to jednocześnie podkreśla pragmatyczny i doczesny wymiar polityki $\mathrm{i}^{10}$. Podejście to stanowi istotne novum w szesnastowiecznych tekstach politycznych, ponieważ nie jest ani utopistyczną projekcją, ani nie wykazuje eudajmonistycznych inklinacji.

${ }^{8}$ M. Šišak, Polikarp, Petrić i Gučetić i pitanje početka hrvatske političke znanosti, „Politička misao" 1994, nr 3, s. 153-168.

${ }^{9}$ A. Miloradović, T. Cipek, M. Šišak, Hrvatska politološka tradicija, Zagreb 1995, s. 19.

${ }^{10}$ Wśród merkuriuszy idei polityki wymienia się także Juraja Križanicia (1618-1683) i jego pracę pt. Politika ili razgovor ob vladateljstvu (wydaną we fragmentach dopiero w 1947 roku). 


\section{Ku nowoczesności}

Istotnym źródłem pozwalającym poznać współczesne rozumienie idei polityki są projekty zawarte w pismach politycznych i mowach działaczy zaangażowanych w wieku XIX w ruch iliryjski - lokalną wersję romantycznych ruchów odrodzeniowych. Rytm rozwoju nowoczesnej myśli politycznej na ziemiach chorwackich dyktowany był ich aktualną sytuacją w obrębie Monarchii Austro-Węgierskiej, w związku z czym najważniejszymi tematami dysput politycznych były relacje z Austrią i Węgrami, chorwacka autonomia i jej zakres, integracja pozostających pod różnymi wpływami ziem, przyszłość Bośni i Hercegowiny, a także kwestia relacji z Serbami (tzw. srpsko pitanje). Politykę zdominowała myśl narodowa i wynikające $\mathrm{z}$ niej wszelkie działania mające na celu utrzymanie status quo ziem chorwackich. Każdy z forsowanych scenariuszy politycznych, bez względu na to, czy opowiadano się za utrzymaniem względnej autonomii pod skrzydłami Węgier, czy pod auspicjami Austrii ${ }^{11}$, pozwala obserwować zjawisko narodzin podmiotowości politycznej społeczeństwa chorwackiego (w modelu narodowym), a co za tym idzie potrzebę określenia tożsamości zbiorowej, poprzedzoną poszukiwaniem i ustalaniem wspólnych wartości. Chorwaccy literaturoznawcy zgodnie podkreślają, że w XIX wieku politykami byli głównie ludzie pióra, duchowieństwo i arystokracja ${ }^{12}$, co zapewne nie pozostawało bez wpływu na rozwój przekonania, że to kultura pełni funkcję ewolucyjną i emancypacyjną, w związku z czym jest obszarem ze swej natury politycznym ${ }^{13}$. Polityka staje się wobec tego obszarem zarządzania przestrzenią symboliczną - językiem i kulturą (zarówno materialną, jak i niematerialną) - wychodząc poza doczesność i sięgając sfery aksjologicznej. Reformy kulturalne jako sposób kształtowania i zarządzania nową wspólnotą były istotnym elementem programu ilirystów (np. Ljudevit Gaj), a następnie większości wybitnych jednostek działających w przestrzeni publicznej (np. Josip Juraj Strossmayer, Antun Radić, Franjo Rački). Tożsamość, której formowanie zajmowało dziewiętnastowiecznych chorwackich działaczy, jest zjawiskiem

${ }^{11}$ Za pierwszy program polityczny, który wychodził poza regulację stosunków z Wiedniem i Budapesztem, ale stanowił również propozycję polityki wewnętrznej rozumianej jako „budzenie" świadomości narodowej (również wśród kobiet), regulację prawa, walkę o język chorwacki oraz rozwój nauki, uważa się pracę polityka i pisarza Janka Draškovicia Disertatia iliti Razgovor darovan gospodi poklisarom z 1832 roku. Inspiracją dla jej powstania był traktat Umowa społeczna Jana Jakuba Rousseau. Pod wpływem lektury francuskiego filozofa Drašković ufundował swoją koncepcję polityki na haśle „wolność, równość i braterstwo”, opowiadając się za kierunkiem reformistyczno-liberalnym w polityce.

${ }^{12}$ M. Šicel, Hrvatska književnost 19. i 20. stoljeća, Zagreb 1997, s. 49-55; S. Prosperov Novak, Povijest hrvatske književnosti. Od Baščanske ploče do danas, Zagreb 2003, s. 177-200.

${ }^{13}$ Znaczący wpływ na sposób myślenia o kulturze wśród chorwackiej inteligencji mieli niewątpliwie Johann Gottfried Herder i August Ludwig von Schlözer. Koncepcja Herdera została przeszczepiona na lokalny grunt dzięki pośrednictwu słowackiemu, a szczególnie osobie Jana Kollára, z którym kontakty utrzymywał przywódca ilirystów Ljudevit Gaj. 
relacyjnym, co oznacza, że dla każdego „my” muszą zostać zdefiniowani „oni” lub - jak pisze Mouffe - musi zostać ustanowiona granica między wnętrzem i zewnętrzem ${ }^{14}$. O ile szesnastowieczne koncepcje opisywały politykę jako dążenie do szczęścia i dobrobytu, a zatem działanie skierowane do wewnątrz, o tyle immanentną częścią programów dziewiętnastowiecznych jest wyraźna obecność różnie definiowanego „konstytutywnego zewnętrza” ${ }^{15}$, którego obecność jest przestrzenią potencjalnego agonu i/lub antagonizmu.

W drugiej połowie wieku XIX spór i konflikt stają się wreszcie fundamentem polityki, zarówno tej obejmującej zarządzanie relacjami z zewnętrzem, jak i tymi wewnątrz wspólnoty. Sprzyjał temu coraz intensywniej rozwijający się na ziemiach chorwackich pluralizm polityczny. Jednym z najbardziej charakterystycznych programów był radykalny ruch niepodległościowy tzw. prawaszów (Stranka prava) pod przywództwem ideologa i pisarza Ante Starčevicia, doskonale sprawdzającego się w politycznych polemikach. Wychodząc od tezy Arystotelesa o jedności polityki i etyki oraz od założenia, że polityka to wiedza, „która uczy zarządzać państwem, innymi słowy - uszczęśliwiać je"16, Starčević rozumie politykę jako umiejętność utrzymania wspólnoty ludzi (państwo). Podążając za swoją fascynacją ideami rewolucji francuskiej, definiuje on działanie polityczne jako dążenie do suwerenności, kształtowanie umowy społecznej i dbałość o własność prywatną, a pozostając pod wpływem lektury Johna Locke'a, Voltaire'a, Monteskiusza, Jana Jakuba Rousseau i Immanuela Kanta, proponuje liberalno-demokratyczny model polityki. Celem Starčevicia nie jest jednak zinstrumentalizowanie państwa i sprowadzenie go do narzędzia demonstracji siły, a polityki do techniki rządzenia. Ambicje polityka sięgają ponad poziom doraźności: celem jest wypracowanie cnoty (krjepost) i dobrobytu (blagostanje), a zatem wspólnego szczęścia, które osiągnąć można między innymi na drodze oświecenia. Politykę w tej koncepcji konstytuują więc prawa i narzędzia do osiągania szczęścia przez lud/naród.

Koncepcja Starčevicia jest wyraźnym nawiązaniem zarówno do starożytnej filozofii polityki, jak i jej szesnastowiecznych lokalnych adaptacji. Na uwagę zasługuje explicite wyrażony mariaż polityki i etyki, zjawisko nazwane przez Mouffe „moralizowaniem polityki”"17 - w którym działanie polityczne przybiera formę quasi-religijną, odnosząc się do wyższego bezwarunkowego porządku. Jednym z przejawów tego fenomenu może być podstawienie w miejsce wroga lub politycznego oponenta kategorii zła (w opozycji do „my” utożsamianego $\mathrm{z}$ dobrem). Celem takiego dualistycznego podziału jest wytrącenie argumentów przemawiających za tym, by uprawiać agoniczną, a zatem uznającą prawo

\footnotetext{
${ }^{14}$ Ch. Mouffe, Agonistyka..., s. 56.

${ }^{15}$ Ibidem, s. 20.

${ }^{16}$ A. Starčević, Politika, „Pozor” 1860, nr 6, s. 1.

${ }^{17}$ Ch. Mouffe, Agonistyka..., s. 144.
} 
przeciwnika do sporu, politykę z ideologicznym oponentem. Jedynym możliwym działaniem jest więc dążenie do całkowitego wyeliminowania przeciwnika. Starčević ujawnia takie inklinacje w swoim stosunku do Serbów, którym odbierał prawo do uznania za odrębny naród. W jego retoryce obecne były wymyślne i nierzadko zawoalowane obelgi, jak choćby „rasa slawoserbska” - synonim prymitywizmu, niewolniczej mentalności i destrukcyjnej odśrodkowej siły wyhamowującej ewolucję. W świetle teorii Mouffe polityka Starčevicia wydaje się momentem założycielskim dla polityki rozumianej jako obszar sporu. Programowa wściekłość (notabene członków partii nazywano steklišami - wściekłymi) chorwackiego polityka, a także jego stosunek do konstytuującego chorwacką tożsamość zewnętrza, pozwalają rozpoznać ten model jako antagonistyczny. Inny, w relacjach z którym niemożliwy jest jakikolwiek konsensus, jest nie tyle politycznym oponentem, ile wrogiem, któremu odbiera się fundamentalne prawa. Liczne pisma Starčevicia, mowy, a także rozprawy publikowane w czasopiśmie „Pozor”" oceniane są jako znakomite pod względem literackim, ale jednocześnie nieprzebierające w środkach ${ }^{19}$. Polityczne nieprzejednanie Starčevicia stało się nawet przyczyną spektakularnych politycznych konwersji, czego najlepszym przykładem jest rewizja poglądów jednego z przedstawicieli chorwackiego realizmu literackiego, Ksavera Šandora Gjalskiego, który „dokonał literackiego obrachunku ze starčeviciowskim radykalizmem własnej młodości”20 . Autor przedstawił Starčevicia w powieści $U$ noći (1886) pod postacią zjadliwego demagoga Pavla Bolicia, którego działalność ocenił jako destrukcyjną dla chorwackiej polityki. Zupełnie inaczej widział rolę Starčevicia jeden z najważniejszych chorwackich pisarzy wieku XX, Miroslav Krleža, który pisał o nim, że jest „,jedynym temperamentem i jedyną głową, która była w stanie osiągnąć proroczą siłę językowej ekspresji”21. Alternatywna dla chorwackiego ekskluzywizmu Starčevicia koncepcja jugosłowiańska (zakładająca zjednoczenie religijne i narodowe Słowian południowych), promowana przez koncyliacyjnego i lojalnego dworowi wiedeńskiemu biskupa Josipa Juraja Strossmayera, wydaje się w tym świetle pozbawiona jakiegokolwiek politycznego żaru. Dali temu dobitnie wyraz pisarz Antun Kovačić, w powieści pt. U registraturi (1888) parodiujący Strossmayera w postaci moralnie wątpliwego Mecenasa, a także Miroslav Krleža, który napisał o nim: „I biskupa Strossa widziałem we mgle, jak baba na rondlu, siedział na cegle"22.

${ }^{18}$ Vide A. Starčević, Politika, s. 1; A. Starčević, Diplomacija, „Pozor” 1860, nr 17, s. 1; A. Starčević, Zajednica, „Pozor” 1860, nr 33, s. 1-2; A. Starčević, Protivnik i dielnici, „Pozor” 1860, nr 44, s. 1-2.

${ }^{19}$ J. Rapacka, Leksykon tradycji chorwackich, Warszawa 1997, s. 174.

${ }^{20}$ Ibidem, s. 179.

${ }^{21}$ M. Krleža, Predgovor „Podravskim motivima” Krste Hegedušića, Zagreb 1933.

${ }^{22}$ M. Krleža, Ballady Pietrka Kerempuha, tłum. A. Dukanović, Warszawa 1983. 
Podejmowane środki i stosowana retoryka wskazują, że dziewiętnastowieczni ideolodzy z pewnością rozumieli politykę jako działanie na rzecz uczynienia własnej interpretacji hegemoniczną, choć sami zapewne jej w ten sposób nie definiowali. Nie można jednak pominąć faktu, że polityka w tym czasie jest nadal jeszcze wyłącznie domeną elit. W związku z tym agoniczny model mógł się realizować jedynie w najwyższym segmencie chorwackiego społeczeństwa. Zmiany w tym zakresie miały nastapić dopiero w kolejnym stuleciu.

Zupełnie inne inspiracje dla formowania idei polityki odczytać można w działalności poety i językoznawcy Ivana Mažuranicia (1814-1890), którego uważa się za pierwszego nowoczesnego chorwackiego polityka, skoncentrowanego nie tylko na chorwackiej autonomii, ale także na reformach wewnętrznych. Mažuranić, który swoją aktywność polityczną godził z najwyższymi obowiązkami w ówczesnym państwie, zainfekowany ideami rewolucji francuskiej zreformował administrację, wprowadził niezależne sądownictwo, zlikwidował resztki feudalizmu, wspomógł założenie pierwszego uniwersytetu, wprowadził obowiązkową edukację na poziomie podstawowym, prawo wolności druku i wolności zgromadzeń, rozszerzył również prawo wyborcze. W chorwackiej tradycji politycznej zwykło się uważać go za przedstawiciela liberalizmu oraz wyraźną alternatywę dla postaw Strossmayera i Starčevicia. Swoje poglądy wyraził między innymi w służbowym dokumencie Manifest narodu chorwacko-slawońskiego (Manifest naroda hrvatsko-slavonskoga, 1848) oraz w dokumencie Hrvati Mađarom (1848), uważanym za jeden z najznakomitszych w tamtym czasie tekstów pisanych (rytmizowaną) prozą. Nie tylko erudycja Mažuranicia, który we wspomnianym tekście artykułuje odrębność Chorwatów i Węgrów, powołując się jednocześnie na ideę braterstwa, ale również dowodzący literackiego wysmakowania styl tego dokumentu oraz jego forma zdradzają stosunek polityka do uprawianej przez niego działalności (list został napisany po chorwacku i węgiersku, co miało zagwarantować, że polityczne postulaty formułowane w Zagrzebiu dotrą do politycznych adwersarzy na Węgrzech). Mažuranić musiał więc zdawać sobie sprawę, że polityka to agon, którego nierozłączną częścią jest nie tylko konflikt, ale także bezpośredni i otwarty dialog z oponentem.

\section{Ku nowym podmiotowościom}

Na przełomie wieków XIX i XX doszło do dwóch zasadniczych transformacji, które miały istotny wpływ na formułowanie koncepcji politycznych i idei polityki jako takiej. Historyk Stjepan Matković ocenia, że zmiany te były ściśle związane z zadomowieniem się w tym czasie na obszarze kultury chorwackiej koncepcji modernizacyjnych ${ }^{23}$. Kwestia narodowa nie pozostawała $\mathrm{z}$ nimi w konflikcie,

${ }^{23}$ S. Matković, Elementi moderniteta u programima i programatskim spisima hrvatskih političkih stranaka od početka 20. stoljeća do prvoga svjetskog rata, Zagreb 2006, s. 162-163. 
ponieważ w bardziej rozwiniętych częściach Europy to właśnie państwo narodowe stanowiło cechę polityczną nowoczesnej historii. Chorwacka Partia Postępowa (Hrvatska napredna stranka, założona w 1904 roku) głosiła konieczność politycznego rozwoju, afirmując podejście racjonalne i wiedzę naukową oraz opowiadając się za ideami demokratyczno-pluralistycznymi, które wspomagały przejście od agrarnego modelu społeczeństwa do modelu industrialnego. W programie partii zawarto deklarację o odejściu od dotychczasowego historyzmu, który oznaczał nieustanną afirmację „chlubnej przeszłości” i pragnienie jej powrotu, na rzecz realizmu oznaczającego trzeźwe rozumienie teraźniejszości i spojrzenie w przyszłość. Drugim czynnikiem determinującym przeobrażenia sposobów myślenia była zmiana pokoleniowa w szeregach partii politycznych, która wpłynęła na poszerzenie ich programów o wolności obywatelskie (m.in. wolność wyrażania poglądów, druku, zgromadzeń, nauki), nienaruszalność cielesną, równość wobec prawa czy prawo do głosowania. Fundamentalną rolę odegrały tu środowiska „postępowców”, a samo pojawienie się pojęcia „postęp” było dowodem wejścia koncepcji modernizacyjnych do polityki. Młodsza generacja sięgała po coraz bardziej radykalne środki działania. Pisarz Vladimir Čerina w tekście Naša riječ w czasopiśmie „Val” pisał:

\footnotetext{
W kwestii narodowej jesteśmy nacjonalistami, a nie szowinistami. Nasza myśl narodowa jest i chorwacka, i serbska, nasza narodowość jest serbsko-chorwacka... Nasz pogląd na świat nie jest dogmatyczny ani religijny, oparty jest na zasadach naukowych. Jako grupa jesteśmy areligijni. Na zewnątrz jesteśmy radykalną opozycją dla całego naszego życia publicznego, wszystkich, którzy nas prowadzą, podejmują decyzje, zarządzają. Naszej sympatii nie ma ani jedna nasza partia polityczna ${ }^{24}$.
}

Nowa generacja wchodziła na scenę pod hasłem „nowej polityki”, pragnąc zamienić salonową i dyplomatyczną taktykę „starych” mniej lub bardziej radykalnym działaniem wymierzonym w zupełnie inaczej zdefiniowanego oponenta politycznego. Konflikt, opór, niezgoda i różnica stają się podstawowym wyznacznikiem polityki młodego pokolenia, które wykluczało możliwość jakiegokolwiek konsensusu. Jego miejsce zajęły radykalne gesty, które na planie literackim wyrażały się w awangardowym ikonoklazmie. Nowością tego czasu są także programy pozostawiające na boku kwestię narodową, działające zaś w kontekście konkretnego problemu, co w przyszłości zaowocuje powstaniem nowych podmiotów politycznych, w tym również organizacji i ruchów międzynarodowych. Niezgodą na dotychczasowy sposób zarządzania sprawami państwowymi była na przykład tzw. „polityka »nowego kursu «" uprawiana przez chorwackich i serbskich aktywistów w obawie przed germanizacją Dalmacji (Drang nach Osten).

${ }^{24}$ V. Čerina, Naša riječ, „Val” 1911, nr 1, s. 1. 
Przyczyniła się ona do intensywnej współpracy lokalnych działaczy ze środowiskami węgierskimi i włoskimi.

Koniec I wojny światowej w chorwackiej historiografii rozumiany jest jako definitywne zakończenie wieku XIX i charakterystycznej dla niego polityki. Transformację tę najlepiej ilustruje działalność polityczna Stjepana Radicia (1871-1928), który politykę rozumiał jako oddanie głosu ludowi. Upolitycznienie tej warstwy społecznej uważane jest za moment przełomowy, ponieważ oznacza odejście od modelu polityki jako domeny warstw uprzywilejowanych. Radić, który był pierwszym wykształconym chorwackim politologiem (studia ukończył w Paryżu), w tekście Hrvatski ideali wyjaśnia, że warunkiem prawdziwej wolności - do której dążyć ma polityka - jest przejęcie władzy przez lud ${ }^{25}$. Celem nadrzędnym niezmiennie pozostaje zjednoczenie Chorwatów we własnym państwie i zapewnienie mu jak największej samodzielności. Jednak dążenie do niezależności powinno wiązać się jednocześnie $\mathrm{z}$ utworzeniem frontu dla nowej siły politycznej, a następnie przyznanie całemu ludowi jednolitych praw, dostępu do oświaty i jak największego dobrobytu. Postulowane wyłonienie (się) nowego podmiotu politycznego ma więc skutkować zmianą w obrębie idei polityki, która od teraz powinna rozwijać się w kierunku zarządzania prawami człowieka i sprawami społecznymi. Szczególną uwagę Radić poświęcił procesowi demokratyzacji polityki, wykazując się przy tym doskonałą znajomością poglądów Machiavellego, Monteskiusza, Voltaire'a i Rousseau ${ }^{26}$.

Praktycznym rozwiązaniom towarzyszyła również refleksja naukowa ${ }^{27}$. Badacze upowszechniali pogląd, że polityka to nie tylko działanie praktyczne (przede wszystkim na rzecz państwa), ale także metarefleksja. Pisarz i tłumacz Josip Andrić (1894-1967) - pozostając pod wpływem czeskich i niemieckich źródeł intelektualnych zgłębionych podczas studiów w Pradze i Innsbrucku - przekonywał w tekście pt. Politika kao nauka z 1926 roku, że „nie może orać ten, kto nie miał w rękach nigdy pługu" 28 . Uczulał on, że polityka oferowana jest narodowi „jak towar na bazarze”, naród zaś zwykle daje się zwieść i podąża

${ }^{25}$ S. Radić, Hrvatski ideali, „Hrvatska misao” 1897, nr 1, s. 5-6.

${ }^{26}$ S. Radić, Savremena Evropa: ili, Karakteristika evropskih država i naroda, Zagreb 1905. Na poglądy Radicia wpływały też lektury tekstów Spencera, Durkheima i Smitha.

${ }^{27}$ Początek instytucjonalnej formy chorwackiej politologii związany jest ze studiami polityczno-administracyjnymi założonymi w Varaždinie w 1769 roku przez cesarzową Marię Teresę (w 1772 roku przeniesione zostały do Zagrzebia). Celem tak sprofilowanego kierunku studiów było wykształcenie aparatu urzędniczego, który miał stanowić rodzaj asysty przy przeprowadzaniu reform w duchu absolutyzmu oświeconego, a następnie piastować urzędy w zreformowanym organizmie państwowym. Słuchaczami kierunku byli przede wszystkim członkowie rodzin arystokratycznych.

${ }^{28}$ J. Andrić, Politika kao nauka, w: A. Miloradović, T. Cipek, M. Šišak, Hrvatska politološka tradicija, Zagreb 1995, s. 223. 
za tym, kto da więcej i taniej. Autor wyróżnia kilka rodzajów polityków: geniuszy i wizjonerów, politycznych dyletantów i agitatorów, którzy wykonują zadania zlecone przez partie, a także zawodowych polityków, którzy czerpią z tej dziedziny działalności korzyści, co Andrić ocenia negatywnie. W jego opinii najgorszy typ przedstawiają politykierzy (politikastri), którzy wciąż mówią o polityce, ale w rzeczywistości tylko odtwarzają to, co pisze prasa ${ }^{29}$. Zdaniem Andricia polityka to działanie kreatywne wykluczające odtwórczość, wymagające talentu. Autor zwraca uwagę na towarzyszące polityce afekty, które mogą jednak być zwodnicze, czego dowodem jest podyktowany sercem chorwacki wybór polityki jugosłowiańskiej (wspólnej z Belgradem), będący wyborem błędnym. Andrić jednoznacznie krytykuje Machiavellego, uważając, że w polityce obowiązują zasady moralne o podłożu chrześcijańskim; odrzuca przekonanie, że moralność narodu i jednostki to dwie rozłączne sfery; uznaje istnienie zasad bezwarunkowych - polityka w modelu idealnym kieruje się zasadą „nie czyń drugiemu, co tobie niemiłe". Na uwage zasługuje tu powrót postrzegania polityki jako domeny państwa, a co za tym idzie - całkowite pominięcie interesów poszczególnych grup społecznych. Koncepcja Andricia ignoruje działania oddolne, nie uwzględniając tym samym możliwości polityki agonicznej.

Odmienne podejście prezentuje natomiast prekursor chorwackiej geopolityki, historyk Ivo Pilar (1874-1933), zwracając uwagę na znaczenie położenia geograficznego jako czynnika determinującego politykę. W pracy pt. Diktat geopolitičkog položaja (1924), powołując się na przykład Wielkiej Brytanii jako państwa doskonale wykorzystującego swoje położenie geopolityczne, Pilar wyraża opinię, że warunkiem politycznej integralności Chorwatów, której brak wynika ze specyficznego położenia na przecięciu różnych stref wpływów w tym przede wszystkim Wschodu i Zachodu - jest osiągnięcie społecznej, politycznej, ekonomicznej i kulturalnej wyższości w regionie. Autor uznaje tym samym praktyki hegemoniczne (rozumiane dodatkowo w kluczu deterministycznym - Chorwaci są ze względu na swoje położenie geopolityczne zarówno skazani, jak i predestynowani do przywództwa) za warunek sine qua non nowoczesnej polityki.

\section{Z powrotem ku iluzji agonistyki}

Po II wojnie światowej i powstaniu Titowskiej Jugosławii politykę w pierwszej kolejności utożsamia się z działaniem Partii Komunistycznej, a następnie decyzjami dotyczącymi spraw wewnętrznych i zagranicznych podejmowanymi przez Josipa Broza Titę. Rozumiano ją jako utrwalanie systemu samorządowego socjalizmu poprzez wpajanie społeczeństwu jego zasad, przekonywanie

\footnotetext{
${ }^{29}$ Ibidem, s. 225.
} 
o konieczności pracy na rzecz rozwoju państwa i rzekomo równego podziału nadwyżki dóbr ${ }^{30}$. Polityka oznaczała zatem instytucjonalną budowę nowego systemu, w którym tworzono iluzję uczestnictwa obywateli w procesie podejmowania decyzji politycznych. Kulturą polityczną, której kształtowanie było jednym z zasadniczych celów socjalistycznych władz, Zdravko Tomac - chorwacki polityk i pisarz - nazywa wyrażanie przez obywateli swojego zdania, składanie propozycji w kwestii organizacji społecznej, aktywność w rozmaitych instytucjach „niebezpośredniej socjalistycznej demokracji" i w organizacjach społeczno-politycznych, a tym samym wpływanie na rozwiązywanie poszczególnych problemów. Paradoksalnie zatem w jednobiegunowym socjalistycznym świecie, w którym polityka nierzadko stanowiła narzędzie opresji, rozwijano - przynajmniej w teorii - ideę polityki partycypacyjnej ufundowanej na modelu agonicznym i tworzono iluzję politycznych sporów. Brak alternatywy wobec dominującego porządku hegemonicznego był jednak doskwierający, a ci, którzy chcieli stawiać opór, aż do końca lat sześćdziesiątych nie znaleźli prawomocnych form ekspresji.

Mimo prób odgórnego łagodzenia konfliktów wewnętrznych chorwacką politykę zajmowała także kwestia relacji chorwacko-serbskich. W perspektywie teorii Mouffe można to interpretować jako element procesu sankcjonowania własnego Innego, konstytutywnego dla własnej tożsamości zewnętrza. Protesty nazwane „chorwacką wiosną” (1971) odbywały się pod hasłem „czyste rachunki” i „sprawiedliwy podział dewiz”, ale w rzeczywistości stanowiły próbę wymknięcia się serbskiemu centralizmowi i oceniane są jako dążenie do narodowej emancypacji podszytej pragnieniem uznania niezależności Chorwatów. Podobnie jak w wieku XIX kwestie polityczne dotyczyły nie tylko spraw administracyjnych i ekonomicznych, ale także statusu języka chorwackiego (Deklaracija o nazivu i položaju hrvatskog književnog jezika, 1967). W zagrzebskim środowisku akademickim skupionym wokół czasopisma „Politička misao” podejmowano w tym czasie refleksję nad naturą polityki. Symptomatyczny wydaje się tekst Inteligencija i politika, w którym politolog Jovan Mirić wyraził przekonanie, że żaden intelektualista nie może być apolityczny, zwłaszcza w czasie, kiedy polityka została „pierwszą społeczną siłą współczesnego świata”31. Mirić - antycypując niejako słynne stwierdzenie Carol Hanisch: „prywatne jest polityczne” - dostrzega fakt, że niemożliwe jest niezaangażowanie w politykę. W sposób szczególny dotyczy to przedstawicieli inteligencji, którzy wyrażają swój stosunek do świata, tworzą rzeczywistość, a tym samym kreują politykę. Zadanie intelektualisty-polityka polega na stałym zmienianiu świata. Polityka jest zjawiskiem dynamicznym,

${ }^{30}$ Z. Tomac, Politička kultura i društveno-političke organizacije, „Politička misao: časopis za politologiju" 1970, nr 1, s. 13-14.

${ }^{31}$ J. Mirić, Inteligencija i politika, „Politička misao” 1966, nr 1-2, s. 20. 
rozgrywającym się $\mathrm{w}$ sferze praxis, a ponadto nie ma końca, osiągnięcie celu oznacza konieczność wyznaczenia kolejnego ${ }^{32}$. Działania polityczne nie są więc ukierunkowane na osiągnięcie konsensusu. W koncepcji Miricia czytelne jest przesłanie obecne w refleksji Mouffe - polityka jest niekończącym się agonem, a polityczność to konfrontacja różnych wizji społeczeństwa w sferze publicznej.

\section{Ku nowym sporom}

Proklamowanie w 1990 roku niepodległości Chorwacji, które przedstawiano jako realizację „tysiącletniego snu” o własnej państwowości, stanowiło cel chorwackiej polityki od połowy wieku XIX. Oprócz kształtowania się parlamentaryzmu i spraw związanych z państwem, ważną kwestią wchodzącą w obręb chorwackiej polityki było formowanie nowoczesnej tożsamości narodowej. Filozofka i socjolożka Vesna Pusić pisała, że zasadniczy konflikt polityczny w latach dziewięćdziesiątych w Chorwacji nie wynikał z różnic w programach politycznych partii, ale $\mathrm{z}$ odmiennych wizji tego, kto i według jakich wartości oraz wzorów ukształtuje chorwacką tożsamość i jej obraz na zewnątrz ${ }^{33}$. Niepodległość, która miała być celem samym w sobie, okazała się czasem początku nowych koncepcji polityki. Stała się ona przede wszystkim obszarem podobnie zresztą jak w wieku XIX - sporów o strategie kreowania obrazu historii, pamięci i tożsamości narodowej. Ostatnie dziesięciolecie wieku XX minęło pod znakiem antagonizmu chorwacko-serbskiego, który przeobraził się w krwawy konflikt. Autorytarny, nacjonalistyczny i konfrontacyjny charakter rządów pierwszego prezydenta niepodległej Chorwacji - Franja Tuđmana - paradoksalnie ukonstytuował jednak agonistyczny model demokracji. Kształtowaniu zbiorowych form identyfikacji towarzyszyły namiętności i afekty stanowiące jego siłę napędową. Tożsamość chorwacką budowano opierając się na uznaniu fundamentalnej różnicy miedzy Chorwatami i Serbami, czego wyrazem była chociażby polityka językowa. Praktyki hegemoniczne nie dotyczyły jednak tylko relacji między zwaśnionymi narodami, ale przede wszystkim odbywały się wewnątrz społeczeństwa chorwackiego. Zaangażowanie w politykę - wyrażane demonstracjami, powstawaniem kolejnych organizacji pozarządowych, poszerzaniem się grupy ekspertów i działaczy komentujących rzeczywistość polityczną - dobitnie pokazuje, że polityka stała się nie tyle obszarem sporu o wartości, ile konfliktu o ich znaczenie i zakres. Potwierdzają to słowa Vlada Gotovaca - największego oponenta Tuđmana, a jednocześnie poety, eseisty i krytyka literackiego który w jednej ze swoich mów zaznaczył, że polityka nie może kwestionować podstawowych wartości własnej cywilizacji, ponieważ czyniąc to przyczynia się

\footnotetext{
${ }^{32}$ Ibidem, s. 22.

${ }^{33}$ V. Pusić, Upotreba nacionalizma i politika prepoznavanja, „Erasmus” 1994, nr 8, s. 2-21.
} 
do destrukcji świata ${ }^{34}$. Śmierć Tuđmana, która przyniosła kres twardych rządów, przyczyniła się do całkowitego przeobrażenia polityki. Przejęcie władzy w 2000 roku przez ugrupowania lewicowe przyczyniło się znacząco do przeobrażenia dwubiegunowego świata w prawdziwe polityczne pluriwersum cechujące się otwartym współzawodnictwem o sferę polityczną i dominację w niej.

Prześledzenie idei polityki formułowanej przez chorwackich polityków i pisarzy pokazuje, że mimo powszechnego przekonania agon i agoniczność wcale nie są immanentną częścią polityki. Szczególną uwagę zwraca zbieżność zjawisk z okresu odrodzenia narodowego i lat dziewięćdziesiątych XX wieku - podobieństwo w sposobach rozumienia idei polityki i przesunięcie jej do sfery kultury. Nie każda ze wspomnianych koncepcji ustanawia konflikt jako wartość. Wiele z nich zdaje się być projektami utopistycznymi zakładającymi - przynajmniej w teorii - możliwość politycznej zgody. Brak aprobaty dla takiego postrzegania zarządzania przestrzenią wspólną wyraża wstępująca na scenę polityczną na początku wieku XX młoda generacja twórców i działaczy politycznych, której pojawienie się jest ściśle związane z rozkwitem awangardy (zarówno pierwszej, jak i drugiej). Ich rewolucyjny gest, stanowiący jednocześnie swoisty atrybut wszystkich młodych pokoleń, zostanie powtórzony na przełomie wieków XX i XXI. Pielęgnowanie przez środowiska twórcze i zaangażowane idei konfliktu wokół zagadnień społecznych i kulturowych, skutkując negacją mitu racjonalnego konsensusu, wyznaczy tory polityki w nowym stuleciu i - oby na trwałe - wpisze polemikę i opór w chorwacki pejzaż kulturowy.

\section{Bibliografia}

Andrić, Josip, Politika kao nauka, w: Hrvatska politološka tradicija, red. A. Miloradović, T. Cipek, M. Šišak, Zagreb 1995.

Čerina, Vladimir, Naša riječ, „Val” 1911, nr 1.

Filozofijski rječnik, red. V. Filipović, Zagreb 1984.

Gotovac, Vlado, Što je rekao Gotovac?, „Vijenac” 1994, nr 4.

Krleža, Miroslav, Predgovor „Podravskim motivima” Krste Hegedušića, Zagreb 1933.

Krleža, Miroslav, Ballady Pietrka Kerempuha, tłum. A. Dukanović, Warszawa 1983.

Matković, Stjepan, Elementi moderniteta u programima i programatskim spisima hrvatskih političkih stranaka od početka 20. stoljeća do prvoga svjetskog rata, Zagreb 2006.

Miloradović, Anđelko, Tihomir Cipek, Marinko Šišak, Hrvatska politološka tradicija, Zagreb 1995.

Mirić, Jovan, Inteligencija i politika, „Politička misao” 1966, nr 1-2.

Mišić, Anto, Riječnik filozofijskih pojmova, Zagreb 2000.

Mouffe, Chantal, Paradoks demokracji, thum. W. Jach et al., Wrocław 2005.

${ }^{34}$ V. Gotovac, Što je rekao Gotovac?, „Vijenac” 1994, nr 4, s. 2. 
Mouffe, Chantal, Agonistyka. Polityczne myślenie o świecie, tłum. B. Szelewa, Warszawa 2015.

Politika [hasło], w: Leksikon Jugoslavenskog Leksikografskog Zavoda, Zagreb 1974.

Prosperov Novak, Slobodan, Povijest hrvatske književnosti. Od Baščanske ploče do danas, Zagreb 2003.

Pusić, Vesna, Upotreba nacionalizma i politika prepoznavanja, „Erasmus” 1994, nr 8. Radić, Stjepan, Hrvatski ideali, „Hrvatska misao” 1897, nr 1.

Radić, Stjepan, Savremena Evropa: ili, Karakteristika evropskih država i naroda, Zagreb 1905.

Rapacka, Joanna, Leksykon tradycji chorwackich, Warszawa 1997.

Šicel, Miroslav, Hrvatska književnost 19. i 20. stoljeća, Zagreb 1997.

Šišak, Marinko, Polikarp, Petrić $i$ Gučetić i pitanje početka hrvatske političke znanosti, „Politička misao” 1994, nr 3.

Starčević, Ante, Politika, „Pozor” 1860, nr 6.

Starčević, Ante, Diplomacija, „Pozor” 1860, nr 17.

Starčević, Ante, Zajednica, „Pozor” 1860, nr 33.

Starčević, Ante, Protivnik i dielnici, „Pozor” 1860, nr 44.

Tomac, Zdravko, Politička kultura i društveno-političke organizacije, „Politička misao: časopis za politologiju” 1970, nr 1 .

EWA WróbleWSKA-TrochimiUK, dr nauk humanistycznych w zakresie kulturoznawstwa, slawistka, kroatystka. Adiunkt w Instytucie Slawistyki Polskiej Akademii Nauk. Autorka monografii Sztuka marginesów. Chorwacki plakat polityczny (2018). Zajmuje się badaniem sfery wizualnej oraz idei politycznych w kulturach południowosłowiańskich. Aktualnie kieruje projektem dotyczącym wizualnych artykulacji oporu politycznego w Serbii i Chorwacji po $2000 \mathrm{r}$. (SONATA NCN). 